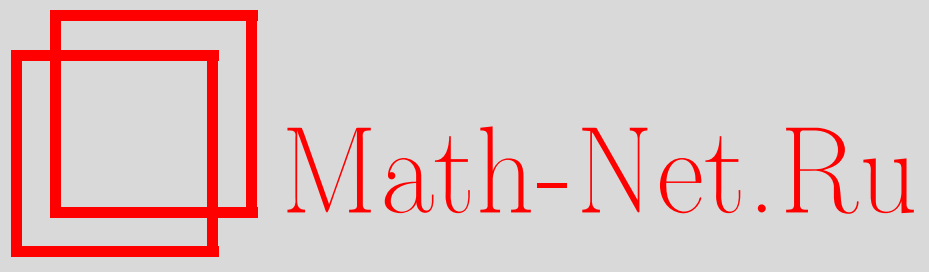

K 80-летию Юрия Викторовича Новожилова, ТМФ, 2006, том 148, номер 1, 3

DOI: https://doi.org/10.4213/tmf2066

Использование Общероссийского математического портала Math-Net.Ru подразумевает, что вы прочитали и согласны с пользовательским соглашением http://www . mathnet.ru/rus/agreement

Параметры загрузки:

IP : 3.85 .5 .30

26 апреля 2023 г., 13:07:16

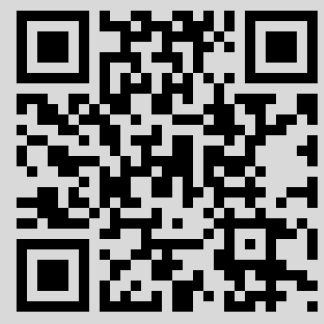




\section{К 80-летию Юрия Викторовича Новожилова}

Юрий Викторович Новожилов известен широкому кругу физиков в России и за рубежом как первоклассный ученый в области квантовой теории поля и физики элементарных частиц, талантливый воспитатель научной молодежи и выдающийся организатор в науке. Будучи непосредственным учеником Владимира Александровича Фока и унаследовав у него на длительный срок должность заведующего отделом теоретической физики Ленинградского (Санкт-Петербургского) университета, он, в свою очередь, подготовил девять докторов и двадцать кандидатов наук, так что можно с полным правом говорить о научной школе Ю. В. Новожилова.

Первым значительным циклом научных работ Ю. В. Новожилова были статьи об облаченных частицах в квантовой теории поля, за которые автор получил университетскую премию первой степени (1960 г.) и был удостоен степени доктора физикоматематических наук (1959 г.). Затем им были выполнены циклы работ по методу функционалов в квантовой теории поля, релятивистской теории спин-изоспиновой симметрии, унитарным представлениям обобщенной группы Пуанкаре и формулировке квантовой теории поля на световом конусе, содержащие важные результаты. Серию из более чем 15 публикаций Ю. В. Новожилов с сотрудниками посвятили новому подходу бозонизации в мезонной физике, основанному на киральной и конформной аномалиях. В работах Ю. В. Новожилова и его учеников была корректно сформулирована и развита идея об индуцированной гравитации А. Д. Сахарова и Я. Б. Зельдовича. Всего Ю. В. Новожиловым опубликовано более 130 статей.

Параллельно научной работе Юрий Викторович на постах заведующего кафедрой, проректора, декана вел большую организаторскую деятельность. В начале семидесятых годов университет строил новый комплекс в Петродворце, и все тяготы переезда ложились на декана физического факультета Ю. В. Новожилова.

В 1973 году Ю. В. Новожилов был направлен в Секретариат ЮНЕСКО в Париже для работы в качестве директора департамента научной политики и информации и заместителя директора сектора науки. Классическое воспитание, полученное им в семье петербургских интеллигентов, и яркие личные научные достижения позволили ему в течение восьми лет достойно представлять в ЮНЕСКО науку нашей страны и отстаивать ее интересы. В год празднования столетия со дня рождения А. Эйнштейна Юрий Викторович был награжден ЮНЕСКО серебряной медалью А. Эйнштейна.

Юрий Викторович написал четыре книги (из них два учебника), которые переведены на английский и другие языки и пользуются широкой известностью. Он является вице-президентом Евразийского физического общества, членом Совета ЮНЕCKO по физике, членом Международной ассоциации математической физики.

Несмотря на свой преклонный возраст, Юрий Викторович продолжает писать научные статьи, работать с аспирантами, читать лекции студентам, каждый год он проводит Международную школу ЮНЕСКО по физике для молодых ученых, труды которой публикуются в журнале "Теоретическая и математическая физика".

Мы желаем Юрию Викторовичу доброго здоровья, бодрости и творческой активности еще на многие годы. 